\title{
Rembrandt EnTERPRises, Broken EgGS
}

\author{
KeVIN KimLe
}

Dave Rettig is President of Rembrandt Enterprises, one of the largest egg producers in the United States. Rembrandt focuses on supplying egg ingredients to food manufacturers and egg products to food service companies. A startup in 2000, Rembrandt went on to become one of the largest companies in the industry in its first five years by implementing an aggressive vertical integration strategy and approaching its growth in an entrepreneurial fashion. This case focuses on Rettig's approach to dealing with a problem arising from a co-product, inedible eggs, at the company's egg-breaking facility. The case charts Rettig's economic analysis of the business opportunity and the decision to create a new line of business.

\section{Rembrandt Enterprises}

"Is another line of business really what this company needs right now," wondered Dave Rettig as he maneuvered his car around another construction vehicle at Rembrandt Enterprises. Rettig was founder and President of Rembrandt Enterprises, one of the largest egg producers in the United States. Rembrandt focused on supplying high quality egg ingredients to food manufacturers, and outstanding egg products to foodservice companies. Rettig founded the company in 2000. Its site in Northwest Iowa was now, in 2007 , home to 16 barns with 5.4 million laying hens, a feed mill, and an egg-breaking facility. The latest construction project was an improved scale and unloading facility for farmers delivering their corn and

Kevin Kimle is the Rastetter Chair of Agricultural Entrepreneurship, a faculty member of the Department of Economics, and Director of the Agricultural Entrepreneurship Initiative at Iowa State University. Teaching notes for this case study are available from the author on request. This article was presented during an invited paper session at the 2010 AAEA annual meeting in Denver, $\mathrm{CO}$. The articles in these sessions are not subject to the journal's standard refereeing process. soybeans, one of a number of initial and more recent projects that had transformed a 160 acre field into a sprawling egg production location.

Rembrandt Enterprises went from startup in 2000 to being one of the top ten companies in the egg industry within its first five years by implementing an aggressive vertical integration strategy and approaching its continued growth in an entrepreneurial fashion. The topic of the meeting Rettig had just left related to an issue that stretched his vision of exactly how far vertical integration would carry Rembrandt Enterprises into new lines of business. In particular, the question was what should he do now that the exclusive customer for inedible eggs, those eggs that are cracked or broken, had informed Rembrandt that it would no longer pay for this co-product of egg production, but rather wanted to be paid for transporting it from Rembrandt's facilities?

Rettig and his father, Darrel, already owned an egg production facility in Ridgeway, Missouri by the 1990s. As time went on, however, they began to brainstorm about creating a vertically integrated egg company; one that would control most of the activities in the production and delivery of eggs, from grinding the feed for the chickens to breaking the eggs and creating products and food ingredients from them. "The broiler industry and more recently the pork industry had companies which had created huge economic efficiencies and competitive advantage through vertical integration, and the egg industry seemed ripe for the same kind of changes," said Rettig.

The egg industry in the 1990s was in the midst of change. Between 1970 and 1989, total annual consumption of shell-eggs and egg products declined steadily by about 4 eggs per person per year, from 309 to 237 eggs. Much of the decline in shell-egg consumption after 1970 was due to health concerns related to cholesterol intake and changing lifestyles, which resulted in less preparation of eggs for breakfast consumption. 
Changing consumer attitudes toward eggs in the 1990s to some degree started to slow the trend in declining shell-egg consumption. For example, the American Heart Association increased its maximum recommended consumption from three eggs per week to four.

Perhaps of more significance was the increase in the consumption of egg products, which nearly doubled between 1980 and 2000. Egg product consumption continued to increase as consumers purchased more prepared foods. By $2000,71 \%$ of eggs were sold to consumers in the shell, while $29 \%$ were broken and sold as products, either fresh liquid eggs, frozen, or dry. In 1990, 20\% of eggs were sold as products.

"The trend toward use of eggs in product form, rather than as shell-eggs, was an important part of our business plan," said Rettig. "It was a way for us to bring continuous innovation to our customers."

\section{The Start}

Rettig and his father put together the earliest business plan for Rembrandt Enterprises in the mid-1990s. "The plan continued to evolve as time went on, but the underlying principle of the business, economic efficiency through vertical integration, was the constant. The more time I spent talking to potential investors, the more excited I became."

The challenge for the business was the capital needed to start the company. "Starting a company like this required a significant amount of capital, so forming up a group of investors that were interested in that big of a bet in this industry was a challenge."

The breakthrough connection came from a friend in Northwest Iowa who also had interests in the egg business, Mike Gidley. "He told me about a businessman from the Twin Cities who had done a small land deal with that might be interested in investing in an egg company. His name was Glenn Taylor.'

The phone call came a few weeks later. "The caller identified himself as Glenn Taylor. He said he'd read the business plan for Rembrandt Enterprises and was interested in meeting to discuss it further. When I got home, I typed his name into an Internet search engine and found out Glenn was founder and chairman of Taylor Corporation, a multinational company in the printing and electronics businesses with more than 10,000 employees, as well as owning the Minnesota Timberwolves NBA franchise. He was on the Forbes billionaires list!"

The meeting took place shortly thereafter, and the group discussed Rettig's vision for a vertically integrated egg company, a business that went well beyond laying hens. The business plan detailed a highly automated egg operation that would break eggs and sell them as egg products in liquid form. "Most restaurants are not breaking eggs in their kitchens," explained Rettig at the meeting.

The meeting with Taylor and his representatives went well. Rettig had found the investor he needed to implement his business plan. Work began shortly thereafter on locating the facilities on a 160 acre farm Taylor owned a few miles east of the town of Rembrandt, Iowa (population 223). By 2001, the first chickens were housed on the site and the first eggs were broken in 2002 .

\section{The Economics of the Early Business Plan}

The first economic premise of Rembrandt's business plan was the cost advantage of locating production in Iowa. Feed costs represent $60 \%$ of egg production costs, and Iowa is the largest corn and soybean producing state. Iowa was the largest egg producing state as recently as 1958, when farm flocks dominated the industry, but new production technology enabled the industry to grow near population centers on the east and west coasts, and production in Iowa declined in the 1960s (Lawrence et al. 2003).

"One chicken eats about one bushel of corn per year and one third a bushel soybeans," said Rettig. "We figured that we had a 20 to 30 cent per bushel advantage in buying corn and soybeans compared to competitors outside Northwest Iowa, so our 2 million bird business plan had about a $\$ 1$ million competitive advantage from cheaper feed ingredients alone."

Table 1 reveals the magnitude of Iowa's corn price advantage over other major layer production states using data from the USDA from 1995 to 2001, the time period when Rembrandt's early business plan was developed. The values in the table represent the frequency that Iowa's monthly average corn price advantage is within the ranges listed in the column on the left. For example, the difference between Iowa's and Georgia's monthly average corn prices was between 45 and 60 cents per bushel $23.5 \%$ of the time, between 60 and 75 cents 
Table 1. Iowa's Corn Price Advantage Versus Other Major Egg Production States, 1995 to 2001

Iowa's Corn

Price Advantage Georgia Ohio Pennsylvania

\begin{tabular}{lrrr}
\hline (\$/bu) & ---- & $-(\%)--$ & --- \\
$<0.00$ & 2.9 & 2.9 & 0.0 \\
$0.00-0.15$ & 1.5 & 40.6 & 2.9 \\
$0.15-0.30$ & 8.8 & 44.9 & 1.5 \\
$0.30-0.45$ & 8.8 & 5.8 & 4.4 \\
$0.45-0.60$ & 23.5 & 2.9 & 38.2 \\
$0.60-0.75$ & 33.8 & 1.4 & 33.8 \\
$<0.75$ & 20.6 & 1.4 & 19.1 \\
\hline
\end{tabular}

Source: United States Department of Agriculture

$33.8 \%$ of the time, and greater than 75 cents $20.6 \%$ of the time (table 1 ).

Rettig wasn't alone in recognizing the potential feed cost advantage of locating in Iowa, however. In 2001, Iowa regained its status as the top egg producing state, virtually at the same time that Rembrandt's production came on-line. Whereas capital investment in egg production prior to the 1980s often occurred closer to east or west coast population centers to minimize egg shipping times and distances, more recent capital investment was in facilities that would minimize feed costs. The trend toward increased processed eggs, improved transportation, and integrated facilities encouraged investment in Iowa egg production to capture its significant feed cost advantage (Lawrence et al. 2003).

"The primary economic disadvantage of locating egg production in Iowa was distance to major population centers," said Rettig. "But our plan was to break the eggs and not ship shell eggs. This focus on egg products reduced the importance of transportation costs compared to shipping whole eggs for retail sales. Our business plan was to locate the feed mill, laying barns, and egg breaking facility at the same site. The raw economics of our plan was to take transportation costs out of our end products relative to our competition. We built the company around reduced feed costs by locating in the heart of corn and soybean country and co-location of all the facilities required to produce innovative egg products" (table 2).

\section{Broken Eggs}

Rembrandt's egg-breaking facility is highly automated. Eggs enter the breaking facility on a conveyor that runs under the banks of chicken house crates. The eggs are then cleaned by a machine with brushes that scrub the eggs in a soapy water solution. Next, the eggs continue on the conveyor to a candling area, where workers inspect eggs with the aid of lights that shine up through the eggs from below.

Eggs next move on to the breaking machine if they pass inspection. Pincers pick up the eggs, and a knife breaks each egg. One breaking machine can process more than 150,000 eggs per hour.

Dirty eggs are sent back to the washer and broken or cracked eggs are separated from the rest, as they cannot be used in products for human consumption. These inedible eggs end up in dried form in animal feed or pet food products. The proportion of eggs that are broken or cracked and inedible, by weight, is 4 to $8 \%$ for most companies in the industry. Using these figures, Rettig was looking at 7 to 14 million pounds of inedible eggs annually for 2007 for Rembrandt.

"Our two major co-products were chicken litter and inedible eggs," explained Rettig. "We developed a niche business selling the chicken litter to local farmers as a replacement for synthetic fertilizers. It is a great product for plant nutrients and soil tilth and enables us to capture additional value from our production process. As prices for synthetic fertilizer rose so did the price of the chicken litter."

The litter business was a responsibility given to Scott Wicks, VP of Purchasing at Rembrandt. "Scott deals with farmers on a daily basis for purchasing corn," said Rettig. "They are the customers for the litter also, so it made a lot of sense to run the chicken litter business simply as an extension of Scott's existing responsibilities of dealing with farmers and the logistics of moving product around the area surrounding our production facilities."

"Up to that point in time, we hadn't put as much thought into the inedible eggs. We had one buyer, a pet food ingredient manufacturer, which took $100 \%$ of that product. The price of inedible eggs is determined by its own supply and demand conditions, but generally hovered around 50 cents per pound, sometimes 15 cents per pound less, sometimes 15 cents per pound more."

"We had a decent relationship with the buyer of the inedible eggs, but things got strained as margins in the industry tightened in 2006. They called us in 2006 and informed us that things were economically tough in their business and they would no longer be able to pay for the 
Table 2. Economic Advantages from Early Business Plan Relative to Competition

\begin{tabular}{llc}
\hline Aspect of Business Plan & Economic Advantage & $\begin{array}{c}\text { Gross Advantage for } \\
2 \text { million Bird Operation }\end{array}$ \\
\hline $\begin{array}{l}\text { Location in Northwest } \\
\text { Iowa }\end{array}$ & $\begin{array}{c}20-30 \text { cents/bushel cheaper } \\
\text { net cost for corn and } \\
\text { soybeans }\end{array}$ & $\$ 1.0$ million \\
$\begin{array}{l}\text { Co-location of feed mill, } \\
\text { layer barns, and egg } \\
\text { breaking facility }\end{array}$ & $\begin{array}{l}3-4 \text { cents/dozen eggs } \\
\text { TOTAL }\end{array}$ & $\$ 1.5$ million \\
PER DOZEN EGGS & & $\begin{array}{c}\$ 2.5 \text { million } \\
6-8 \text { cents }\end{array}$ \\
\hline
\end{tabular}

inedible eggs. They would, however, continue to pick them up at their own expense and truck them the 500 miles to their manufacturing facility where they were dried and prepared for use in animal feed and pet food products. We didn't have any idea what else to do with them and we had few relationships in the animal feed business to peddle the product somewhere else, so we quit charging for the inedible eggs."

By the summer of 2007, the relationship took another turn. "It was probably predictable, but we got a call from the buyer again explaining the tough economic environment for their business. Their proposal was now that they still could not pay for the inedible eggs, but they also could not afford to transport them to their manufacturing facility. If we would pay for that transportation, about 5 cents per pound, they would still take the inedible eggs."

\section{Inedible Eggs as a New Line of Business}

The pace of expansion at Rembrandt Enterprises had put the company at about 7 million layers under its management by 2007. "We had an incredible amount of things going on, and the last thing I wanted to think about was a new line of business for the animal feed industry, where we had no existing business," said Rettig.

Rettig relied on economics to guide his decision. "I decided to look at the economics of this new potential line of business. We didn't have any expertise in providing ingredients to the animal feed industry, but if I can enter the business with a significant cost advantage, we will have room to make mistakes while we learn the ropes."

This occurred at the same time that Rembrandt was considering a new product line based on dried eggs. Adding driers to their production facilities would enable Rembrandt to sell to companies that supply food ingredients to baking companies and makers of egg noodles, mayonnaise, sauces, and candy. Another market for dried egg products was the food service sector, which would be a new market for Rembrandt, one that would include customers such as distributors who sell to hospitals, schools, and prisons. "If we were going to add driers for new products for food customers, we could also dry the inedible eggs on site and save the costs involved with shipping inedible liquid eggs. Animal feed and pet food companies utilize eggs in dried form anyway. We would need to buy different driers for the inedible eggs than we use for eggs that go for food use, but it seemed like there would be some efficiencies in using driers for both edible and inedible egg products."

One of the issues that made this co-product different from chicken litter was the new market it represented. Rembrandt did not sell products in the animal feed market, and Rettig questioned whether it made sense to add those responsibilities to anyone already at the company. "My initial bias was to separate this new line of business into a subsidiary company. It just felt like a start-up company kind of opportunity to me and was different enough from anything else at Rembrandt that it should be a stand-alone entity."

Over the next few weeks Rettig spent some time talking to contacts he was able to identify in the animal feed business. On a quiet afternoon at the office he wrote on his yellow pad regarding the short list of relevant issues regarding the potential start of a new line of business.

\section{ECONOMICS}

- Inedible liquid eggs - $88 \%$ water and $12 \%$ solids.

- Inedible liquid egg average price of 50 cents/lb. 
- Transportation costs for 500 miles - 5 cents/lb.

- Inedible liquid eggs for Rembrandt - 7 million lbs. 2007, 14 million lbs. 2010.

- High product quality.

\section{STRUCTURE OF NEW BUSINESS}

- Strategic focus - Food vs. animal feed?

- Management focus?

- Potential proportion of sales that for export is high.

- New division or new separate/subsidiary company?

Rettig looked at the bullet points on his yellow pad and considered his decision. The incremental investment in developing the capacity to dry the inedible eggs is not significant given Rembrandt's commitment to egg drying machinery for food use anyway. But how does he present the economic opportunity to his partners and employees? What is the best way to structure this new line of business? He needs to arrive at a decision soon, or he is going to be paying another company to haul away the inedible eggs.

\section{Discussion Questions:}

1. How does Rettig rely on economic analysis to form a business plan?

2. Which economic principles have been used in Rembrandt's founding and growth, and how do they apply to the potential formation of a new line of business?
3. How does Rettig assess the risks associated with entering a new market? Are there issues he may not be considering that could change his view on the potential of this market that are important?

4. What is your recommendation for Rettig regarding inedible eggs? Why?

\section{Endnote}

In 2009, Rembrandt Enterprises acquired one of its major competitors, Golden Oval. Golden Oval, a member-owned cooperative based in Minnesota, produced shell-eggs and processed them into liquid products. The company had production and processing facilities in Minnesota and Iowa, with additional processing and distribution operations in Missouri, California, and Alabama.

The acquisition was a significant one for Rembrandt, with the total value of the transaction worth over $\$ 100$ million. The post-acquisition Rembrandt has almost 700 employees, and a laying hen count of over 14 million. With the Golden Oval acquisition, Rembrandt Enterprises became the thirdlargest egg producer in the United States after Cal-Maine Foods and Rose Acres.

Growth in egg production in Iowa from the 1990s was signficant, with an increase of over 25 million laying hens between 2000 and 2010. As the industry adopted a more vertically integrated structure, Iowa's share of U.S. production rose from $9.0 \%$ in 2000 to $18.9 \%$ in 2010 (Table 3).

Table 3. Layer Inventories for Top 10 States, 2000 Versus 2010

\begin{tabular}{|c|c|c|c|c|c|}
\hline \multicolumn{3}{|c|}{2000} & \multicolumn{3}{|c|}{2010} \\
\hline State & $\begin{array}{l}\text { Layers } \\
(1,000)\end{array}$ & $\begin{array}{c}\% \text { of U.S. } \\
\text { Prod. }\end{array}$ & State & $\begin{array}{l}\text { Layers } \\
(1,000)\end{array}$ & $\begin{array}{c}\text { \% of U.S. } \\
\text { Prod. }\end{array}$ \\
\hline Ohio & 31,129 & 9.7 & Iowa & 53,447 & 18.9 \\
\hline Iowa & 28,098 & 9.0 & Ohio & 27,302 & 9.6 \\
\hline Penn. & 23,275 & 7.5 & Indiana & 23,123 & 8.1 \\
\hline Calif. & 24,056 & 7.5 & Penn. & 22,555 & 8.0 \\
\hline Indiana & 22,708 & 7.2 & Calif. & 19,223 & 6.8 \\
\hline Georgia & 20,816 & 6.1 & Texas & 13,411 & 4.7 \\
\hline Texas & 17,423 & 5.2 & Mich. & 10,104 & 3.5 \\
\hline Arkansas & 15,340 & 4.2 & Minn. & 9,953 & 3.5 \\
\hline Minn. & 12,581 & 3.9 & Nebr. & 9,382 & 3.3 \\
\hline Nebr. & 11,909 & 3.6 & Florida & 9,272 & 3.3 \\
\hline 10 States & 207,335 & 63.7 & 10 States & 197,772 & 69.9 \\
\hline
\end{tabular}


As of 2010, there are 61 egg producing companies in the United States with 1 million plus layers, and 13 companies with greater than 5 million layers. There are approximately 192 egg producing companies with flocks of 75,000 hens or more, which represent about $95 \%$ of all the layers in the United States. In 1987, there were around 2,500 operations in the United States with flocks of 75,000 or more (American Egg Board 2010).

\section{References}

American Egg Board. 2010. Available at: http://www.aeb.org/egg-industry/industryfacts/egg-industry-facts-sheet. (Accessed April 30, 2010).

Lawrence, J., G. May, D. Otto, and J. Miranowski. 2003. "Economic Importance of the Iowa Egg Industry." Department of Economics Working Paper, Iowa State University. 
lowa State University does not discriminate on the basis of race, color, age, religion, national origin, sexual orientation, gender identity, genetic information, sex, marital status, disability, or status as a U.S. veteran. Inquiries can be directed to the Director of Equal Opportunity and Compliance, 3280 Beardshear Hall, (515) 294-7612. 